\title{
PENGARUH KEMAMPUAN TEKNIS AUDITOR TERHADAP KUALITAS INFORMASI LAPORAN KEUANGAN
}

\author{
Annisa Rahmawati \\ bumigora80@gmail.com \\ Universitas 45 Surabaya \\ Asmara Indahingwati \\ Sekolah Tinggi Ilmu Ekonomi Indonesia \\ Achmad Daengs, GS \\ Universitas 45 Surabaya
}

\begin{abstract}
This study intends to provide empirical evidence and a discussion of the influence of the auditor's technical capabilities built by the dimensions of knowledge, experience, and communication on the quality of information presented in the financial statements. This research is a quantitative research using explanatory method. The subjects of this study are public accounting firms located in East Java. The sample used in this study is the auditor who has carried out work at a public accounting firm in East Java with a length of service of at least two years. The type of data used in this study is primary data derived from questionnaires. The statistical analysis method used in this study is Structural Equation Modeling. From the data collection that has been done, the elaboration of this research shows that there is a significant positive impact between the auditor's technical ability on the quality of financial statement information. This result indicates that the better the technical capabilities possessed by the auditors concerned, the better the quality of the information presented in the audited financial statements.
\end{abstract}

Key words: audit; technical capabilities; financial statement information

\begin{abstract}
ABSTRAK
Studi ini bermaksud untuk memberikan bukti empiris dan pembahasan tentang pengaruh kemampuan teknis auditor yang dibangun oleh dimensi pengetahuan, pengalaman dan komunikasi terhadap kualitas informasi yang tersaji dalam laporan keuangan. Penelitian ini merupakan penelitian kuantitatif dengan metode eksplanatori. Subyek dari penelitian ini adalah kantor akuntan public yang berlokasi di Jawa Timur. Sampel dalam penelitian ini adalah auditor yang telah melaksanakan pekerjaan pada kantor akuntan publik di Jawa Timur dengan lamanya masa kerja setidaknya dua tahun. Jenis data yang digunakan dalam penelitian ini adalah data primer yang berasal dari penyebaran angket. Metode analisa statistik yang digunakan dalam penelitian ini adalah Structural Equation Modelling. Dari pengumpulan data yang telah dilakukan, penjabaran dari penelitian ini menunjukkan adanya dampak positif signifikan antara kemampuan teknis auditor terhadap kualitas informasi laporan keuangan. Hal ini mengindikasikan bahwa semakin baik kemampuan teknis yang dimiliki oleh auditor yang bersangkutan maka akan semakin baik pula kualitas informasi yang tersaji dalam laporan keuangan auditan.
\end{abstract}

Kata kunci : audit; kemampuan teknis; informasi laporan keuangan

\section{PENDAHULUAN}

Audit ialah proses penelahaan bukti terhadap informasi dalam rangka untuk menilai tingkat kecakapan antara informasi dan pedoman yang telah ditetapkan, dimana proses tersebut dilakukan oleh orang yang memiliki kemampuan yang memadai dan independen dibidang audit (Mkoba dan 
Marnewick, 2016). Audit merupakan proses yang penting karena proses tersebut memberikan keyakinan bahwa informasi keuangan yang terpampang pada laporan keuangan telah disajikan secara wajar dalam segala hal, dimana informasi tersebut berguna bagi para penggunanya, dan akan membawa kepada konsekuensi ekonomi (Francis, 2011). Beberapa fenomena kasus audit yang membawa dampak terhadap para penggunanya diantaranya seperti yang terjadi pada kasus yang menimpa PT Garuda Indonesia, dimana auditor dari kantor akuntan publik ternama dijatuhi sanksi karena informasi yang terpampang pada laporan keuangan auditan dianggap menyesatkan. Kasus audit lain juga pernah menimpa PT Kimia Farma, dimana auditor ternama juga dijatuhi sanksi karena kasus yang serupa. Dari kedua kasus tersebut dapat dilihat bahwa auditor memiliki fungsi penting dalam memberikan garansi kepada masyarakat luas bahwa informasi yang terpampang pada laporan keuangan telah dipaparkan secara wajar dan informasi tersebut menjadi satu dari sumber pertimbangan bagi para pengguna informasi keuangan dalam membuat pertimbangan ekonomi.

Brunelli (2018) memaparkan bahwa kemampuan teknis yang dimiliki auditor merupakan satu dari komponen penentu yang berpengaruh terhadap kualitas informasi yang tepampang dalam laporan keuangan auditan. Dimana dengan kemampuan teknis yang memadai maka diasumsikan bahwa auditor yang bersangkutan lebih cakap untuk menemukan adanya salah saji material serta memiliki kemampuan yang lebih baik untuk memberikan garansi atas kewajaran informasi yang tersaji dalam laporan keuangan (Brunelli, 2018). Pemaparan tersebut disokong oleh beberapa penelitian terdahulu diantaranya Agusti dan Pertiwi (2013), Ilmiyanti dan Suhardjo (2012), serta Tjun et al., (2013) yang memaparkan bahwa kemampuan teknis berdampak positif terhadap kualitas informasi keuangan. Namun demikian, pada kenyata- annya masih terdapat auditor dari kantor akuntan public ternama yang dijatuhi sanksi karena informasi yang mereka berikan dinilai menyesatkan. Ukuran kantor akuntan public itu sendiri sering menjadi patokan kemampuan teknis yang dimiliki oleh auditor yang bersangkutan. Dimana ukuran kantor akuntan yang semakin besar dianalogikan dengan kemampuan teknis yang semakin baik, karena kantor akuntan public besar dan ternama dinilai memiliki sumberdaya yang lebih besar (Francis dan Yu, 2009).

Berdasarkan pemaparan latar belakang diatas maka rumusan masalah dalam penelitian ini adalah:

Apakah kemampuan teknis auditor berpengaruh terhadap kualitas informasi laporan keuangan?

Penelitian ini bertujuan untuk memberikan bukti empiris mengenai pengaruh kemampuan teknis auditor terhadap kualitas informasi laporan keuangan, agar didapatkan tambahan wawasan secara teoritis mengenai pengaruh kemampuan teknis auditor terhadap kualitas informasi laporan keuangan.

\section{TINJAUAN TEORETIS}

Audit ialah proses telaah bukti terhadap informasi dengan tujuan untuk menilai tingkat kecakapan antara informasi dan pedoman yang sudah ditentukan, serta dijalankan oleh pihak yang memiliki kecukupan dalam hal kemampuan teknis dan memiliki sikap tidak memihak (independen) dibidang audit. (Boiral et al., 2019; Christensen et al., 2016; Mkoba dan Marnewick, 2016).

Audit dapat menjadi jasa assurance yang berkualitas apabila auditor yang menjalankan proses audit tersebut mampu untuk memaparkan terjadinya ketidak sesuaian dan kecurangan yang terjadi ketika rangkaian audit berlangsung karena auditor yang bersangkutan memiliki kemampuan teknis yang memadai. Faktor kemampuan teknis merupakan faktor yang berhubungan dengan persepsi bahwa dengan kemampuan teknis yang memadai maka auditor mampu 
untuk mendeteksi kesalahan dan kemampuan teknis juga mencerminkan tiga dimensi yang harus dimiliki oleh auditor yaitu reputasi, kapabilitas dan assurance. Dengan kemampuan teknis yang memadai maka auditor yang bersangkutan dipersepsikan sebagai auditor yang bereputasi, memiliki kapabilitas yang memadai serta sanggup memberikan assurance (jaminan) atas hasil kerja yang telah dikerjakan. Auditor dengan kriteria tersebut diyakini mampu menggunakan informasi teknis dan metode audit yang lebih efektif sehingga dapat menjalakan rangkaian aktivitas audit dengan kualitas yang baik (Butcher et al., 2013; Hussein dan MohdHanefah, 2013).

Tingkat pengetahuan teknis berhubungan dengan pengetahuan. Dimana pengetahuan memiliki dampak signifikan pada sumberdaya yang mereka miliki. Dengan kemampuan teknis yang memadai, auditor dapat mengajukan pertanyaan penting dalam rangka pengumpulan bukti audit yang sesuai yang digunakan sebagai dasar dalam pelaksanaan jasa assurance terhadap informasi yang disajikan dalam laporan keuangan (Steinbart et al., 2012).

Dari penjelasan diatas dapat disimpulkan bahwa audit dapat menjadi suatu proses yang bernilai karena audit merupakan proses yang memiliki kemampuan untuk menyediakan keyakinan yang independen mengenai kredibiltias dari informasi akuntansi yang dapat meningkatkan efisiensi alokasi sumberdaya yang dimiliki oleh entitas yang bersangkutan.

Seiring dengan meningkatnya kompleksitas transaksi usaha dan standar akuntansi, meningkatkan nilai tambah dari rangkaian proses audit yang dilakukan (DeFond dan Zhang, 2014). Brunelli (2018) memaparkan bahwa proses audit dapat dijalankan dengan baik apabila auditor yang bersangkutan memiliki kemampuan teknis yang memadai, yang pada akhirnya akan berakibat pada kualitas informasi laporan keuangan yang disajikan (Brunelli, 2018). Dimana hal tersebut sesuai dengan beberapa teori dasar mengenai audit yaitu Policeman Theory,
Credibility Theory, Information Theory dan The Assurance Theory.

\section{Policeman Theory}

Teori ini merupakan teori yang populer dalam ranah audit pada tahun 1940an. Teori ini menjelaskan bagaimana auditor berperan seperti seorang polisi yang berfokus pada akurasi secara matematis dan melakukan pencegahan terhadap salah saji yang berpotensi untuk terjadi, serta melakukan deteksi terhadap kecurangan (Jönsson dan Ottosson, 2015; Salehi, 2010; Salifu dan Mahama, 2015).

Policeman theory adalah teori yang menjelaskan bahwa audit bersandar pada prinsip akurasi aritmetik dimana auditor berkewajiban untuk mendeteksi dan mencegah terjadinya kecurangan (Dauda dan Olawale, 2019). Namun demikian, seiring dengan berjalannya waktu, focus dari audit telah berpindah dari fungsi verifikasi tentang kebenaran dan kewajaran dari laporan keuangan menjadi keharusan untuk memberikan jaminan yang memadai. Pada perkembangannya, Policeman Theory tidak mampu untuk menjelaskan peran dan tujuan dari auditing. Kelemahan dari Policeman Theory ini kemudian di sempurnakan dalam Credibility Theory (Ajao et al., 2016; Eid dan Mahmoud, 2014).

\section{Credibility Theory}

Teori ini menjelaskan bahwa kemanfaatan fundamental dari audit adalah memperkuat keandalan laporan keuangan. Laporan keuangan auditan, digunakan oleh pengelola perusahaan untuk meningkatkan kepercayaan pihak lain sebagai pengguna informasi keuangan dan menurunkan asimetri informasi. Dimana informasi yang terpampang pada laporan keuangan memiliki fungsi untuk mengkonfirmasi kondisi keuangan perusahaan yang bersangkutan (Hope et al., 2011; Rezaee et al., 2016; Salehi, 2010).

Credibility Theory menjelaskan bahwa kemampuan informasi untuk mempengaruhi para penggunanya akan bergantung 
pada kredibilitas dari informasi tersebut. Sumber informasi yang memiliki kredibilitas tinggi akan lebih berpengaruh dibandingkan dengan informasi berkredibilitas rendah. Kredibilitas dari suatu informasi bersumber dari kemampuan teknis dari penyusun informasi tersebut dan kepercayaan yang dirasakan oleh para pengguna informasi keuangan karena kemampuan teknis yang dipunyai oleh para penyusun informasi keuangan. Kemampuan teknis digambarkan sebagai sumber kekuatan untuk dapat menyusun informasi menjadi suatu pernyataan yang akurat. Oleh karenanya informasi yang disusun oleh mereka yang memiliki kemampuan teknis yang memadai dianalogikan memiliki kredibilitas yang lebih tinggi dibandingkan dengan informasi yang disusun oleh orang yang tidak memiliki kemampuan teknis yang memadai. Jika Credibility Theory ini diaplikasikan pada setting audit, maka dapat dikatakan bahwa semakin obyektif dan kompeten informasi keuangan yang disajikan maka para pengguna informasi akan lebih bersandar terhadap informasi tersebut. Pengguna informasi keuangan mengharapkan untuk mendapatkan informasi dari auditor yang memiliki kemampuan teknis yang lebih memadai dan lebih obyektif sebagai sumber dari kredibilitas informasi keuangan (Arel, 2010; Robertson, 2010).

Berdasarkan Credibility Theory, fungsi utama dari audit adalah untuk menambahkan kredibilitas terhadap laporan keuangan. Laporan keuangan yang teraudit dapat meningkatkan kepercayaan pengguna laporan keuangan terhadap segala informasi keuangan yang terpampang dalam laporan keuangan serta meningkatkan kepercayaan terhadap layanan yang diberikan oleh manajemen perusahaan. Credibility Theory ini menekankan pada kemampuan eksplanatori informasi dalam laporan keuangan untuk memberikan penjelasan yang dapat dipahami oleh pengguna informasi keuangan dalam rangka untuk mengambil keputusan ekonomi (Akther dan $\mathrm{Xu}, 2020$; Eid dan Mahmoud, 2014).

\section{Information Theory}

Pengambilan keputusan merupakan bagian intrinsic dari praktek masa kini dalam ranah akuntansi. Pengambilan keputusan merupakan dasar dari timbulnya permintaan atas layanan yang disuguhkan oleh para akuntan dan hal tersebut melibatkan tugas yang tidak mudah. Pertama, permintaan atas layanan para akuntan, yaitu informasi, adalah sesuatu yang disebabkan oleh mereka yang meyakini bahwa informasi akuntansi akan membantu mereka dalam pembuatan keputusan. Investor, para pemberi pinjaman, pegawai, pemerintah dan manajemen perusahaan merupakan para pihak yang terpengaruh oleh informasi yang disajikan oleh para akuntan. Kedua, akuntan sendiri diperlukan karena adanya keperluan untuk mengambil sejumlah keputusan kompleks. Contohnya, akuntan harus menentukan isi laporan yang akan disajikan kepada para pembuat keputusan, memperkirakan jumlah besaran pajak yang akan disajikan dan memberikan konsultasi akuntansi, berkaitan dengan bagaimana regulasi yang berbeda akan di interpretasikan oleh pihak lain, menentukan bagaimana seharusnya untuk mengkombinasikan hasil dari berbagai informasi yang didapatkan dari serangkaian proses audit untuk menghasilkan pemaparan audit report yang memadai, memperkirakan permintaan layanan audit dalam rangka untuk merencanakan kebutuhan masing-masing personel yang melaksanakan rangkaian proses audit. Kualitas dari keputusan tersebut, akan menentukan keberhasilan para akuntan dalam market place audit. Dalam tujuannya untuk menghasilkan keputusan yang lebih baik, maka terdapat tiga hal yang dapat dilakukan. Pertama, mengubah informasi yang akan disajikan. Kedua, mengedukasi para pembuat keputusan untuk mengubah cara mereka dalam memproses informasi. Ketiga, menggantikan para pengambil keputusan dengan model pengambil keputusan.

Para akuntan akan cenderung untuk melakukan pendekatan pertama, yaitu 
mengubah informasi. Namun demikian, dampak dari pilihan ini tidak terpengaruh oleh keputusan yang berkaitan dengan pilihan lain. Dampak dari perubahan informasi akan dipengaruhi oleh bagaimana informasi digunakan. Terlebih lagi, karakteristik informasi akan berdampak pada cara informasi tersebut diproses. Secara sederhana dapat dinyatakan bahwa penataan informasi dan metode yang digunakan untuk mengolah informasi memiliki dampak interaktif terhadap kualitas keputusan (Libby, 2017).

Laporan keuangan merupakan instrument utama bagi tujuan pengawasan. Instrumen alternative atau instrument pelengkap terhadap prinsip pengawasan adalah prinsip informasi, yang berfokus pada keharusan bahwa informasi harus dapat memungkinkan pengguna dalam mengambil keputusan ekonomi. Investor meminta agar laporan keuangan di audit dalam kaitannya dengan kepentingan mereka untuk melakukan keputusan investasi dan menilai keuntungan yang diharapkan serta risiko yang berpotensi untuk mereka hadapi. Investor menilai audit sebagai suatu kegiatan untuk meningkatkan kualitas informasi keuangan, dimana penjelasan mengenai hal tersebut dijelaskan lebih lanjut dalam The Assurance Theory. Selain itu, audit juga dinilai sebagai suatu kegiatan untuk meningkatkan kualitas data yang digunakan dalam proses pengambilan keputusan internal. Data yang lebih akurat akan dapat meningkatkan pengambilan keputusan internal (Eid dan Mahmoud, 2014).

\section{The Assurance Theory}

Assurance merupakan suatu hal yang berkaitan dengan estimasi yang berkaitan dengan ketidakpastian. Tingkatan dari estimasi tersebut akan berdampak terhadap apa yang dihadapi oleh akuntan public dalam memberikan assurance (jaminan) terhadap perkiraan saldo akun dengan rentang ketidak pastian yang lebih besar jauh lebih besar dibandingkan dengan materialitas atas laporan keuangan secara keseluruhan
(Christensen et al., 2012). Assurance (jaminan) dari laporan perusahaan yang berkesinambungan telah lama menjadi bahan perdebatan. Pengelola perusahaan dan penyedia jasa assurance secara berkala sering kali dituding mengenai apa saja yang harus dilakukan dalam rangka memenuhi kewajiban publik. Esensi dasar dari Assurance adalah bahwa informasi yang dipaparkan oleh perusahaan dianggap lebih terpercaya (credible) jika informasi tersebut telah diperiksa oleh pihak ketiga yang independen. Tujuan dari proses Assurance yang diberikan oleh pihak ketiga adalah untuk memberikan rasa aman dan nyaman kepada mereka yang akan merasa rentan terhadap kepentingan pribadi dari pengelola perusahaan (Smith et al., 2011).

Proses Assurance yang sistematis dapat memberikan level assurance yang dibutuhkan berkaitan dengan informasi yang dipaparkan dalam sebuah laporan dan kualitas dari informasi tersebut karena tanggung jawab dari sistem manajemen dan para pemangku kepentingan telah menjadi lebih spesifik terhadap informasi yang mereka perlukan. Pilihan terhadap penyedia jasa assurance pada akhirnya menggiring pada pilihan kantor akuntan publik yang akan digunakan jasanya. Assurance itu sendiri sangat erat kaitannya dengan kemampuan teknis yang dimiliki oleh auditor yang bersangkutan, karena peran auditor sekarang ini tidak hanya terbatas hanya untuk memberikan assurance (jaminan) terhadap informasi keuangan, tetapi juga telah meluas dari hal tersebut karena adanya peningkatan permintaan dari para pemangku kepentingan akan adanya penyajian informasi yang berkesinambungan (Sawani et al., 2010).

Assurance merupakan alat untuk pengawasan dan pengendalian. Audit merupakan serangkaian proses untuk memberikan jaminan (assurance) sebagai mekanisme pengawasan yang merupakan kesatuan rangkaian dalam hubungannya dengan adanya asimetri informasi antara pengelola perusahaan dengan para pengguna informasi keuangan, dimana pengelola 
perusahaan akan dengan sukarela memberikan jaminan (assurance) kepada para pengguna informasi keuangan. Penjelasan tersebut sesuai dengan pemaparan artikel seminal Watts dan Zimmerman (1983) yang menyatakan bahwa sebagian besar pengelola perusahaan akan dengan sukarela menjadi subyek pemeriksaan berkaitan dengan laporan keuangan perusahaan, dimana tindakan tersebut akan membawa keuntungan bagi para pengelola perusahaan. Hal ini sesuai dengan analogi bahwa audit merupakan serangkaian proses yang dilakukan dalam rangka proses pengawasan untuk memperkuat kredibilitas informasi keuangan perusahaan (Chadegani, 2011; Wong dan Millington, 2014).

Assurance service yang diberikan oleh kantor akuntan publik menggambarkan sebuah kesimpulan mengenai kesimpulan tentang reliabilitas dari pernyataan tertulis mengenai tanggung jawab pihak lain. Dimana dalam Assurance Service terdapat layanan professional independen yang dapat meningkatkan kualitas informasi bagi pembuat keputusan. Tanggung jawab individu untuk membuat keputusan bisnis akan bersandar pada Assurance Service untuk membantu meningkatkan reliabilitas dan relevansi dari informasi yang akan dipakai sebagai dasar bagi keputusan mereka (Eid dan Mahmoud, 2014).

\section{Kemampuan Teknis Auditor}

Kemampuan teknis merupakan konsep yang melibatkan beberapa bidang (misalnya pengetahuan, motivasi, dan komponen pragmatis). Dalam ranah audit, kemampuan teknis dapat diartikan sebagai kemampuan seorang auditor untuk memahami langkah teknis yang harus dilakukan pada saat pelaksanaan rangkaian proses audit (Ziefle dan Schaar, 2010).

Kemampuan yang diperlukan untuk dapat menjadi auditor yang baik adalah tidak hanya memahami tentang akun yang harus di debit atau akun yang harus di kredit dan tidak pula hanya memahami daftar keperluan data atau daftar urutan kegiatan audit. E. F. Schumacher dalam pernyataannya menjelaskan bahwa seorang auditor dapat membaca bukti audit berulang kali agar auditor tersebut dapat memahaminya atau jika tidak, maka auditor tersebut dapat mendefinisikan tujuannya dan menggunakan teknik audit yang dapat memastikan bahwa auditor yang bersangkutan telah mendapatkan apa yang dia cari dalam proses audit serta mendapatkan apa yang dia butuhkan agar dapat menjalankan rangkaian audit dengan baik. Pernyataan Schumacer tersebut jika dilihat lebih dekat memiliki tekanan terhadap auditor. Dengan menitik beratkan pada kegiatan audit pada pernyataan tersebut, maka pernyataan tersebut dapat dimaknai sebagai berikut: Auditor yang bersangkutan dapat melakukan peninjauan terhadap daftar kegiatan audit berkali-kali dalam rangka untuk meyakinkan diri bahwa auditor yang bersangkutan telah melakukan prosedur audit dengan baik dan tertib, atau auditor yang bersangkutan dapat mendefinisikan tujuan audit yang dilakukannya dan menggunakan kemampuan auditnya untuk menjamin bahwa auditor yang bersangkutan telah memenuhi persyaratan untuk mencapai pelaksanaan audit yang baik dan telah mendapatkan apa yang dia perlukan.

Audit adalah proses yang kompleks yang melibatkan berbagai kemampuan dan tanggung jawab yang berbeda. Dan juga, dalam kondisi sekarang ini, auditor akan terus menerus menghadapi peningkatan permintaan akan jasa audit karena tuntutan regulasi dan ekspektasi klien. Pada akhirnya, auditor akan menghadapi tekanan untuk mendokumentasikan dengan baik pekerjaan yang dilakukan dan pada akhir yang lain, auditor menghadapi tekanan untuk melakukan pekerjaan dengan baik, tertib, tepat waktu dan tidak melanggar anggaran yang telah ditetapkan. Tekanan ini dapat mendorong pada jebakan "prioritas untuk melengkapi daftar kegiatan", yang kemudian menjebak auditor yang bersangkutan dalam ilusi kepada auditor bahwa jika dapat menyelesaikan pekerjaan tepat waktu maka 
opini audit yang diberikan pasti akan sesuai. Oleh karenanya jika satu-satunya teknik audit yang dikuasai oleh auditor dalam rangka pelaksanaan audit hanyalah sekedar pemenuhan kegiatan yang tertera dalam daftar kegiatan, maka auditor yang bersangkutan niscaya akan gagal menjadi auditor yang handal.

Kemampuan teknis yang baik merupakan poin fundamental dalam mencapai kesuksesan rangkaian audit. Hal ini bukanlah sesuatu yang baru bagi siapapun dan harus dilihat sebagai dasar dari rangkaian karakteristik yang diharapkan dimiliki oleh semua auditor. Auditor yang baik akan secara berkesinambungan membangun kemampuan teknisnya seiring dengan karirnya, yang disebut sebagai "komitmen untuk belajar sepanjang umur". Melalui karirnya, maka auditor yang bersangkutan harus memiliki dasar-dasar etika dan menghindari sikap "biarkan seperti adanya" ketika dilakukan peninjauan mendalam mengenai permasalahan yang berpotensi untuk menguak adanya kesalahan atau kecurangan. Hal mendasar ini akan bergantung pada area teknis, dimana auditor yang bersangkutan harus menjaga kemampuan teknisnya sepanjang karir. Jika auditor tidak menyesuaikan diri dengan aturan teknis maka auditor yang bersangkutan dapat dengan mudah kehilangan sesuatu yang penting dalam pelaksanaan audit yang mendorong pada penerbitan opini audit yang tidak sesuai

Profesi audit tidak hanya menyangkut tanda centang dan tanda simpul dalam deretan daftar prosedur audit, tetapi audit merupakan hal yang menyangkut manusia. Auditor perlu untuk memiliki pengecualian pada kemampuan seseorang. Auditor perlu untuk memiliki kemampuan untuk berhadapan dengan segala jenis klien dalam segala jenis situasi usaha klien. Dalam situasu tertentu, personel klien memiliki ketakutan terhadap auditor karena mereka tidak suka jika ada orang yang mengintip dari bahu mereka. Jadi auditor harus memiliki kemampuan untuk menempatkan personel klien pada posisi untuk meredakan prasangka mereka dan mampu untuk berempati dari perspektif klien. Adalah juga penting bagi auditor untuk menampilkan rasa hormat terhadap klien. Terlebih lagi, klien adalah pihak yang membayar untuk dijalankannya proses audit. Ketrampilan yang seringkali diabaikan oleh banyak orang adalah ketrampilan untuk mendengarkan. Mendengarkan nampak seperti kemampuan yang sederhana tetapi hanya sedikit yang bisa menjalankannya dengan baik. Banyak auditor mendengarkan sesuatu hanya untuk mendengarkan jawaban yang mereka ingin dengar saja daripada untuk mendengarkan untuk memahami. Sebagian besar daftar kegiatan audit hanya menanyakan pertanyaan close ended yang mencegah klien untuk dapat mengelaborasi situasi. Ketika klien menjelaskan dengan lebih dalam tentang jawaban mereka, maka auditor harus mendengar jawaban klien secara lengkap, ketika auditor kehilangan satu bagian kecil dari jawab tersebut maka hal tersebut dapat mengakibatkan auditor salah menangkap pesan yang disampaikan oleh klien secara keseluruhan. Selain itu, orang yang berkemampuan teknis baik adalah orang yang penting dalam kelompok kerja audit. Oleh karenanya, auditor dengan kemampuan teknis yang baik harus belajar untuk mampu bekerja secara berkelompok agar dapat mencapai tujuan tim kerja secara bersama-sama (Lim et al., 2016).

Brunelli (2018) menjelaskan bahwasanya kualitas informasi yang termuat pada laporan keuangan dari sisi auditor sangat mungkin dipengaruhi oleh dua faktor yaitu, kemampuan teknis auditor dan kualitas layanan atau karakter dari auditor yang bersangkutan yang terdiri dari empati, responsiveness, assurance (Brunelli, 2018). Konsep kemampuan teknis pertamakali dipopulerkan dalam buku manajemen karya Boyatzis (1982) sebagai suatu langkah untuk meningkatkan kinerja individu. Dimana dalam buku tersebut dijelaskan bahwa kemampuan teknis merupakan suatu konsep yang lebih cocok untuk digunakan dalam konteks kinerja dibandingkan dengan kon- 
sep kepandaian karena kemampuan teknis digambarkan sebagai karakteristik individu yang dapat mendorong kepada kinerja yang lebih baik. Secara umum kemampuan teknis dipandang sebagai kemampuan manusia untuk menyelesaikan tugas tertentu dalam sebuah entitas sebagaimana kemampuan entitas tertentu untuk melakukan fungsi tertentu dalam rangka memastikan keberlangsungan operasional dari entitas tersebut. Dalam ranah auditor, terdapat beberapa klasifikasi kemampuan teknis yang harus dimiliki oleh auditor dalam rangka mencapai kinerja yang efektif. Karakteristik ini dapat berupa pengetahuan yang dibutuhkan atau kemampuan untuk menyelesaikan sebuah pekerjaan (Ali et al., 2018).

Kemampuan teknis auditor dalam pelaksanaan tugas dibidang audit, dipaparkan dalam standar umum kesatu (SA seksi 210 dalam SPAP, 2011). Standar tersebut memaparkan bahwa audit harus dijalankan oleh mereka yang memiliki kemampuan serta pelatihan mumpuni yang memadai sebagai auditor. Lebih lanjut, dalam standar umum ketiga (SA seksi 230 dalam SPAP, 2011) dipaparkan bahwa dalam pembuatan laporan keuangan auditan, maka seorang auditor harus menggunakan keahlian profesionalnya dengan sangat teliti. Oleh karenanya, tiap-tiap auditor wajib memiliki sikap professional dan keahlian teknis yang mumpuni dalam pelaksanaan tugasnya sebagai auditor (Publik, 2011)

Kemampuan teknis muncul sebagai sesuatu yang dapat dipahami dari sudut pandang tuntutan pekerjaan dan kualifikasi pribadi. Kemampuan teknis bisa didapatkan dari dua hal yaitu dari pengetahuan dan pengalaman dalam konteks ICT (information communication technology), keterampilan sosial, dan pengelolaan keseluruhan pekerjaan seseorang yang dikoordinasikan diantara para pekerja dalam entitas yang bersangkutan. Pengembangan kemampuan teknis dipandang sebagai bagian penting dalam kemampuan secara keseluruhan. Hal ini dapat cermati dari sudut pandang bahwa kemampuan teknis jelas merupakan sesuatu yang perlu dikembangkan dalam rangka peningkatan kemampuan seseorang dalam kehidupan kerja sejalan dengan perubahan dalam pekerjaan dan lingkungan kerja. Secara khusus, perubahan dalam teknologi informasi dan komunikasi dan pemanfaatannya dipandang merupakan suatu hal yang membutuhkan pembelajaran dan pengembangan, terlepas dari pandangan dari sebagian besar orang bahwa ICT (information communication technology) hanyalah sekedar alat untuk melakukan pekerjaan, dan bukan alat untuk menyusun konten dari pekerjaan tersebut. Kemampuan teknis dapat dikembangkan, terutama melalui pembelajaran di tempat kerja. Diantaranya, pembelajaran terkait dengan komunitas kerja dan pekerjaan itu sendiri. Cara yang paling sering digunakan adalah: berbagi pengetahuan dalam komunitas kerja, pembelajaran mengenai kasus di tempat kerja (misalnya pembelajaran mengenai pemecahan masalah), partisipasi dalam pelatihan, pemahaman terhadap literatur profesional dan sumber informasi lain, kerjasama di luar pekerjaan masyarakat, dan pemanfaatan pengetahuan dan keterampilan yang dipelajari di wilayah kehidupan lainnya.

Pengalaman merupakan salah satu indikator dari pengetahuan teknis yang paling banyak dibahas. Karena pengetahuan teknis lebih banyak menekankan pada metode pembelajaran berbasis kerja, maka pengalaman lebih sering diidentikkan elemen utama yang membangun pengetahuan teknis. Dalam sebuah survey yang dilakukan oleh Paloniemi mengenai kemampuan teknis dengan menggunakan karyawan swasta sebagai respondennya, sumber dari pengetahuan teknis dibagi dari tiga sumber utama yaitu: pendidikan dan pelatihan (kejuruan), pengalaman, dan karakteristik pribadi. Dari survey tersebut sebagian besar responden menjawab bahwa pengalaman merupakan sumber utama mereka dalam mendapatkan kemampuan teknis. Responden memiliki pandangan bahwa peran pengalaman kerja dipandang sebagai sesuatu yang tidak tergantikan dalam 
pengelolaan keseluruhan pekerjaan seseorang, dan dalam pengetahuan yang terkait dengan komunitas kerja dan domain bisnis. Pengetahuan teknis semacam ini dievaluasi sebagai hal yang paling penting dan juga sebagai yang tidak dapat dipelajari melalui pendidikan. Namun demikian, meskipun pengalaman merupakan sumber utama dari kemampuan teknis, tetapi jawaban dari survey yang telah dilakukan juga menyatakan dengan jelas bahwa pengalaman kerja saja tidak cukup. Hubungan antara pendidikan dan pengetahuan teknis berbasis pengalaman menjadi isu yang menarik selama survey dilakukan. Pembahasan tersebut mencakup pembahasan mengenai bagaimana seharusnya pendidikan dan pembelajaran berbasis pengalaman dihubungkan sehingga pendidikan formal dapat dimanfaatkan dalam situasi kerja praktis dan pengalaman kerja dapat membantu seseorang untuk mendapatkan hasil maksimal dari pendidikan formal. Waktu pendidikan dan pengalaman kerja adalah salah satu isu yang direnungkan oleh responden dari sudut pandang pengembangan profesional mereka. Hal ini dipandang sebagai tantangan terutama di bidang Information Communication Technology di mana persyaratan pembelajaran tinggi dan cepat (McNamara, 2013).

Selain pengetahuan dan pengalaman, komunikasi juga merupakan bagian yang membangun kemampuan teknis. Komunikasi yang efektif akan mendatangkan banyak keuntungan bagi suatu entitas. Ketika kemampuan komunikasi menjadi lebih baik maka hal tersebut akan dapat meningkatkan kemampuan suatu entitas dan menjadikan entitas tersebut menjadi lebih efisien. Semakin banyak informasi yang diterima, maka koneksi antar bagian dalam satu entitas akan menjadi lebih baik, hubungan personal menjadi lebih baik dan oleh karenanya dapat meningkatkan performa individu dalam pelaksanaan pekerjaan. Komunikasi yang baik merupakan basis bagi lingkungan kerja yang baik, yang membuktikan bahwa produktivitas akan meningkat seiring dengan kondisi para pekerja yang merasa lebih puas dan bahagia dengan pekerjaan yang mereka kerjakan yang didominasi dengan atmosfir personal yang menyenangkan. Kesalahan informasi pada kenyataannya dapat berdampak pada pekerjaan dalam kelompok kerja yang akan berdampak pada buruknya komunikasi internal. Perubahan yang terjadi, baik itu positif maupun negative, harus di komunikasikan pada seluruh bagian dari entitas atau setidaknya dikomunikasikan pada bagian entitas yang kemungkinan besar akan terdampak. Dengan adanya informasi tersebut akan mendorong mereka yang terdampak untuk tahu bagaimana harus bertindak dan bagaimana harus berhadapan dengan akibat yang mungkin muncul. Dengan memiliki sistem komunikasi yang baik maka hal tersebut merupakan hal yang vital untuk pengambilan keputusan bagi suatu entitas (Oliván, 2017; Steinbart et al., 2012).

Kemampuan komunikasi yang baik akan memungkinkan auditor untuk memiliki hubungan dan penilaian dengan orang lain seperti misalnya, staff lain, manajer, partner dan lien. Dalam dunia teknologi dimana kita tinggal saat ini, teknologi tersebut dapat membawa dampak buruk bagi staff auditor untuk dapat memiliki kemampuan berkomunikasi secara efektif, khususnya ketika email menjadi pengganti untuk berkomunikasi dengan tatap muka secara langsung antara auditor dengan klien yang ditangani.

Auditor yang baik akan memahami pentingnya komunikasi secara tatap muka langsung dan akan berusaha untuk menjadikan komunikasi tatap muka secara langsung menjadi cara komunikasi yang utama. Adalah penting dalam pekerjaan auditor untuk berkomunikasi secara verbal sebagai cara komunikasi utama. Dalam sebagian kasus, email seharusnya menjadi pilihan komunikasi terakhir dibandingkan dengan tatap muka secara langsung. Klien ingin berkomunikasi secara langsung dengan auditor, semakin efektif komunikasi 
yang dilakukan auditor, maka akan semakin baik pembicaraan yang terjadi antara klien dengan auditor. Komunikasi yang efektif akan muncul ketika klien dapat memahami secara jelas apa yang dimaksud dan dikatakan oleh auditor yang bersangkutan. Untuk mencapai hal ini bukanlah sesuatu yang mudah tetapi jika auditor yang bersangkutan dapat mewujudkan komunikasi yang efektif maka pekerjaan audit yang dilakukan akan berjalan seirama dengan komunikasi yang dilakukan (Lim et al., 2016).

\section{Kualitas Informasi Laporan Keuangan}

Kualitas dari informasi yang terpampang dalam laporan keuangan ditentukan oleh nilai dari pelaporan akuntansi. Diseluruh dunia, permintaan akan informasi keuangan memiliki criteria bahwa kualitas dari informasi laporan keuangan tersebut mampu memberikan penjelasan yang jelas dan tanpa ditutup-tutupi. Adalah penting untuk menyediakan pelaporan keuangan dengan kualitas tinggi yang dapat mempengaruhi keputusan investasi dari para pengguna informasi tersebut dan untuk meningkatkan efisiensi pasar. Semakin tinggi kualitas dari pelaporan keuangan, maka akan semakin signifikan keuntungan yang bisa didapatkan oleh investor dan pengguna lain dari laporan keuangan. Terlebih lagi kualitas pelaporan keuangan merupakan konsep yang luas yang tidak hanya merujuk pada informasi keuangan tetapi juga merujuk pada informasi lain yang bersifat non keuangan yang berguna bagi pengambilan keputusan (Herath dan Albarqi, 2017).

Informasi dalam laporan keuangan dapat dikatakan memiliki kualitas apabila memiliki kecukupan tiga kriteria, yakni, Pertama, informasi dalam laporan keuangan dapat memberikan penyampaian yang sesuai berkaitan dengan operasional entitas dalam hal tertentu seperti misalnya arus kas, dalam rangka untuk dapat memberikan penjelasan informasi yang mumpuni kepada para investor. Kedua, informasi dalam laporan keuangan mampu memberikan pemaparan informasi yang wajar mengenai kinerja serta posisi keuangan entitas yang bersangkutan. Ketiga, informasi dalam laporan keuangan merupakan informasi yang transparan dan tidak dirancang untuk memungkinkan adanya penggelapan atau merugikan penggunanya (Achim dan Chiş, 2014; Elbannan, 2011).

Berdasarkan Ikatan Akuntan Indonesia (IAI), audit yang dijalankan auditor bisa disebut sebagai suatu proses yang dapat menghasilkan kualitas informasi laporan keuangan yang memadai apabila dapat memenuhi pedoman dan atau standar auditing. Standar auditing seksi 161 menyebutkan bahwa seharusnya kantor akuntan publik juga mencukupi standar auditing yang telah diatur IAI dalam pelaksanaan audit. Menurut IAI, standar auditing dibagi menjadi tiga bagian, yakni, Pertama, standar umum yang terdiri dari penjelasan mengenai pedoman mengenai siapa yang dianggap mampu untuk menjalankan tugas audit (memiliki kemampuan dan mengikuti proses penataran dibidang audit, memiliki karakter yang tidak memihak dan skeptis). Kedua, standar pekerjaan lapangan yang terdiri dari pertanyaan mengenai perikatan, perencanaan, supervisi, pengumpulan dan pengujian bukti, temuan dan dokumentasi. Ketiga, standar pelaporan yang terdiri dari pertanyaan mengenai diukur dengan indikator pekerjaan sesuai SPAP, review kertas kerja dan review laporan (Publik, 2011).

\section{Pengembangan Hipotesis \\ Kemampuan Teknis Auditor terhadap Kualitas Informasi Laporan Keuangan}

Dalam konteks audit, kemampuan teknis yang dipunyai oleh auditor merupakan salah satu hal penting yang dapat berdampak terhadap kualitas informasi yang di sajikan dalam laporan keuangan (Brunelli, 2018). Kemampuan teknis auditor terdiri dari beberapa unsur diantaranya pengetahuan, pengalaman dan kemampuan komunikasi (McNamara, 2013; Oliván, 2017). Brunelli (2018) menjelaskan bahwasanya kualitas informasi yang termuat pada 
laporan keuangan dari sisi auditor sangat mungkin dipengaruhi oleh kemampuan teknis auditor. Penjelasan Brunelli (2018) ini selaras dengan pemaparan credibility theory bahwa kemanfaatan fundamental dari audit adalah memperkuat keandalan laporan keuangan. Laporan keuangan auditan, digunakan oleh pengelola perusahaan untuk meningkatkan kepercayaan pihak lain sebagai pengguna informasi keuangan dan menurunkan asimetri informasi (Salehi 2010).

Berdasarkan Credibility Theory, fungsi utama dari audit adalah untuk menambahkan kredibilitas terhadap laporan keuangan, dimana laporan keuangan yang teraudit diharapkan dapat meningkatkan kepercayaan pengguna laporan keuangan terhadap segala informasi keuangan yang terpampang dalam laporan keuangan dalam tujuannya untuk mengambil keputusan ekonomi (Eid dan Mahmoud, 2014). Dalam Credibility Theory dijelaskan bahwa kemampuan informasi untuk mempengaruhi keputusan para penggunanya akan bergantung pada kredibilitas dari informasi tersebut. Dimana Sumber informasi yang memiliki kredibilitas tinggi akan lebih berpengaruh dibandingkan dengan informasi berkerdibilitas rendah. Kredibilitas dari suatu informasi bergantung pada kemampuan teknis dari penyusun informasi tersebut dan rasa percaya yang dirasakan oleh para pengguna informasi keuangan. Kemampuan teknis digambarkan sebagai sumber kekuatan untuk dapat menyusun informasi menjadi suatu pernyataan yang akurat. Oleh karenanya informasi yang disusun oleh mereka yang memiliki kemampuan teknis yang memadai dianalogikan memiliki kredibilitas yang lebih tinggi dibandingkan dengan informasi yang disusun oleh orang yang tidak memiliki kemampuan teknis yang memadai.

Jika Credibility Theory ini diaplikasikan pada setting audit, maka dapat dikatakan bahwa semakin obyektif dan kompeten informasi keuangan yang disajikan, maka para pengguna informasi akan lebih ber- sandar terhadap informasi tersebut. Pengguna informasi keuangan mengharapkan untuk mendapatkan informasi dari auditor yang memiliki kemampuan teknis yang lebih memadai dan lebih obyektif sebagai sumber dari kredibilitas informasi keuangan (Arel, 2010; Robertson, 2010)

Penelitian terdahulu yang dilakukan oleh Agusti dan Pertiwi (2013), Ernstberger et al. (2015), Ilmiyati dan Suhardhi (2012), Tjun et al. (2013), Brown et al. (2016). Mendukung paparan logika yang di jelaskan oleh Brunelli (2018) dan paparan logika dari Credibility Theory. Hasil dari penelitian mereka menjelaskan bahwa kemampuan teknis yang dimiliki oleh auditor memanglah faktor penting yang dapat berpengaruh kepada kualitas informasi laporan keuangan, dimana hasil penelitian mereka, memaparkan bahwa kemampuan teknis auditor berpengaruh positif signifikan terhadap kualitas informasi laporan keuangan (Agusti dan Pertiwi, 2013; Brown et al., 2016; Ernstberger et al., 2015; Ilmiyati dan Suhardjo, 2012; Tjun et al., 2013). Namun demikian, disisi lain terdapat beberapa penelitian lain, sebagaimana yang dilakukan oleh Butar-Butar dan Indiarto (2018), Nwanyanwu (2017), dan Suyono (2012) yang menyatakan bahwa pengaruh pengetahuan teknis tidak berpengaruh signifikan terhadap kualitas informasi keuangan (ButarButar dan Indarto, 2018; Nwanyanwu, 2017; Suyono, 2012).

Penelitian ini bermaksud untuk membuktikan paparan logis yang dijelaskan dalam Credibility Teory yang didukung oleh beberapa penelitian terdahulu yang telah dilakukan oleh Agusti dan Pertiwi (2013). Ernstberger et al. (2015), Ilmiyati dan Suhardhi (2012), Tjun et al. (2013), Brown et al. (2016) bahwa kemampuan teknis yang dimiliki oleh auditor berpengaruh positif signifikan terhadap kualitas informasi keuangan. Berdasarkan penjelasan tersebut maka hipotesis dalam penelitian ini adalah: Kemampuan teknis auditor berpengaruh positif signifikan terhadap kualitas informasi laporan keuangan. 


\section{METODE PENELITIAN}

Penelitian ini memakai pendekatan metode kuantitatif. Penelitian ini bermaksud untuk menghasilkan pemaparan tentang hubungan antara beberapa variabel, yang di gambarkan dalam bentuk rumus. Rumus tersebut memaparkan hubungan antara variabel yang dipengaruhi dan variabel yang mempengaruhi. Variabel ini merupakan variabel yang tidak bisa secara langsung terukur. (Variabel Laten) (Sarstedt et al., 2014).

Pengujian hipotesa dalam penelitian ini memakai pendekatan Structural Equation Modelling (SEM). Metode ini merupakan generasi kedua setelah metode Regresi. Metode SEM memiliki beberapa keunggulan diantaranya dapat digunakan untuk penelitian dengan variabel yang belum bisa diukur dengan langsung (variabel laten) dengan error yang lebih kecil dibanding dengan metode Regresi. Pengumpulan data pada penelitian ini dilakukan secara survey dengan angket yang dibagikan dalam bentuk butir pertanyaan yang dipakai sebagai alat untuk mengumpulkan data dalam tujuan mendapatkan ilustrasi mengenai variabel penelitian.

Sedangkan data yang digunakan dalam penelitian ini adalah data primer. Data primer adalah data yang di jabarkan secara langsung dari sumber pertama (Amrin, 2016).

Populasi yang digunakan dalam penelitian ini terdiri dari auditor yang melaksanakan pekerjaan pada Kantor Akuntan Publik di Jawa Timur. Adapun sampel dalam penelitian ini terdiri dari auditor yang telah melaksanakan pekerjaan pada kantor akuntan publik di Jawa Timur dengan durasi pelaksanaan pekerjaan minimal dua tahun. Sampel tersebut menjadi pilihan dalam penelitian ini karena auditor dengan masa kerja minimal dua tahun diasumsikan memiliki pengalaman dan keahlian dalam bidang audit yang mumpuni serta mempunyai fungsi fundamental pada saat proses audit berlangsung.

\section{Definisi Operasional}

Definisi operasional dalam penelitian ini adalah sebagai berikut:

a. Kemampuan Teknis Auditor

Kemampuan teknis auditor merupakan suatu hal yang berkaitan dengan pengetahuan dan pengalaman serta kemampuan komunikasi yang memadai dari auditor yang bersangkutan. Karena dengan pengetahuan, pengalaman serta kemampuan komunikasi yang baik maka diharapkan auditor yang bersangkutan dapat melaksanakan audit dengan baik dan dapat menghasilkan opini audit yang dapat memberikan gambaran mengenai kewajaran informasi yang dipaparkan dalam laporan keuangan (McNamara, 2013). Oleh karena itu maka variabel kemampuan teknis auditor dalam penelitian ini diukur menggunakan dimensi pengetahuan, pengalaman dan komunikasi.

b. Kualitas Informasi Laporan Keuangan

Berdasarkan Ikatan Akuntan Indonesia (IAI), audit merupakan suatu proses yang dilakukan agar dapat menghasilkan kualitas informasi laporan keuangan yang memadai. Kualitas informasi laporan keuangan tersebut dapat dikatakan memadai apabila telah memenuhi standar sebagaimana yang telah di jelaskan dalam pedoman standar auditing. Sesuai dengan standar auditing 161, maka kualitas informasi laporan keuangan dalam penelitian ini diukur dengan menggunakan dimensi standar pelaporan umum, standar pekerjaan lapangan dan standar pelaporan (Publik, 2011).

Persamaan struktural menurut metode Structural Equation Modelling adalah sebagai berikut:

Model Pengukuran:

$$
\begin{aligned}
& X_{1}=\lambda_{X_{11}} \xi_{1}+\delta_{1} \quad X_{2}=\lambda_{X_{21}} \xi_{1}+\delta_{2} \\
& X_{3}=\lambda_{X_{31}} \xi_{2}+\delta_{3} \\
& Y_{1}=\lambda_{y_{11}} \eta_{1}+\varepsilon_{1} \quad Y_{2}=\lambda_{y_{21}} \eta_{1}+\varepsilon_{2} \\
& Y_{3}=\lambda_{X_{31}} \eta_{1}+\varepsilon_{3}
\end{aligned}
$$


Model Struktural:

$\eta_{1}=\gamma_{11} \xi_{1}+\zeta_{1}$

Keterangan:

$X_{1}=$ Pengetahuan

$X_{2}=$ Pengalaman

$X_{3}=$ Komunikasi

$Y_{1}=$ Standar Umum

$Y_{2}=$ Standar Pekerjaan Lapangan

$Y_{3}=$ Standar Pelaporan Keuangan

$\xi_{1}=$ Kemampuan Teknis Auditor

$\delta=$ Delta (Ukuran Kesalahan)

$\eta_{1}=$ Kualitas Informasi Laporan Keuangan

ANALISIS DAN PEMBAHASAN

\section{Confirmatory Factor Analysis Pengetahuan} Teknis

Analisa confirmatory factor analysis (CFA) merupakan analisa yang berguna untuk mengetahui validitas konvergen dan reliabilitas konstrak. Validitas konvergen merupakan ukuran yang dapat memberikan penjelasan apakah setiap indikator yang diukur dapat secara sesuai mengukur dimensi dari konstruk yang diuji (Sarstedt $e t$ al., 2014). Hasil analisis faktor konfirmatori mendapati nilai loading factor dan error variance model CFA kompetensi yang dapat dijabarkan pada Tabel 1 berikut:

Tabel 1

CFA Kemampuan Teknis

\begin{tabular}{|c|c|c|c|c|c|}
\hline \multicolumn{3}{|c|}{ Model Pengukuran } & \multirow{2}{*}{$\begin{array}{c}\text { Std Loading } \\
0.701\end{array}$} & \multirow{2}{*}{$\begin{array}{c}\text { Std Loading } \\
0.491401\end{array}$} & \multirow{2}{*}{$\begin{array}{c}\text { Error Variance } \\
0.601\end{array}$} \\
\hline $\mathrm{X}_{1.1 .1}$ & $\leftarrow$ & Pengalaman & & & \\
\hline$X_{1.1 .2}$ & $\leftarrow$ & Pengalaman & 0.664 & 0.440896 & 0.59 \\
\hline$X_{1.1 .3}$ & $\leftarrow$ & Pengalaman & 0.674 & 0.454276 & 0.63 \\
\hline $\mathrm{X}_{1.1 .4}$ & $\leftarrow$ & Pengalaman & 0.549 & 0.301401 & 0.679 \\
\hline$X_{1.2 .1}$ & $\leftarrow$ & Pengetahuan & 0.702 & 0.492804 & 0.568 \\
\hline $\mathrm{X}_{1.2 .2}$ & $\leftarrow$ & Pengetahuan & 0.795 & 0.632025 & 0.438 \\
\hline $\mathrm{X}_{1.2 .3}$ & $\leftarrow$ & Pengetahuan & 0.701 & 0/491401 & 0.57 \\
\hline $\mathrm{X}_{1.2 .4}$ & $\leftarrow$ & Pengetahuan & 0.603 & 0.363609 & 0.73 \\
\hline$X_{1.3 .1}$ & $\leftarrow$ & Komunikasi & 0.789 & 0.622521 & 0.443 \\
\hline$X_{1.3 .2}$ & $\leftarrow$ & Komunikasi & 0.551 & 0.303601 & 0.722 \\
\hline$X_{1.3 .3}$ & $\leftarrow$ & Komunikasi & 0.689 & 0.474721 & 0.578 \\
\hline \multicolumn{3}{|c|}{ Total } & 7.418 & 5.068656 & 6.549 \\
\hline
\end{tabular}

Sumber : data penelitian (2019)

Dengan merujuk pada analisa CFA pada variabel Pengetahuan Teknis yang telah dipaparkan pada Tabel 1, dapat dilihat bahwa semua indikator yang membentuk tiap dimensi pada variabel kompetensi memiliki standar loading yang memiliki nilai melebihi 0,5 . Oleh karenanya dapat disimpulkan bahwa indikator yang membentuk variabel pengetahuan teknis telah memenuhi validitas konvergen.

Untuk mengetahui reliabilitas konstrak variabel kompetensi, akan dihitung nilai construct reliability dan variance extracted dengan rumus sebagai berikut:
Construct reliability $=\frac{\left(\sum \text { stdloading }\right)^{2}}{\left(\sum \text { stdloading }\right)^{2}+\sum e_{i}}$

$=(7,418)^{2} /\left(7,418^{2}+6,549\right)=0,894$

Dari perhitungan diatas, maka didapatkan nilai reliabilitas konstruk sebesar 0,894 . Angka ini melebihi 0,6 sehingga dapat dinyatakan variabel kemampuan teknis auditor telah sesuai dengan construct reliability.

\section{Confirmatory Factor Analysis Kualitas Informasi Laporan Keuangan}

Variabel kualitas informasi laporan keuangan disusun oleh berdasarkan model second order dari tiga dimensi yaitu standart 
pekerjaan umum, standart pekerjaan lapangan dan standart pelaporan keuangan. Hasil analisis faktor konfirmatori men- dapati nilai loading factor dan error variance model CFA kualitas audit yang dapat dilihat pada Tabel 2.

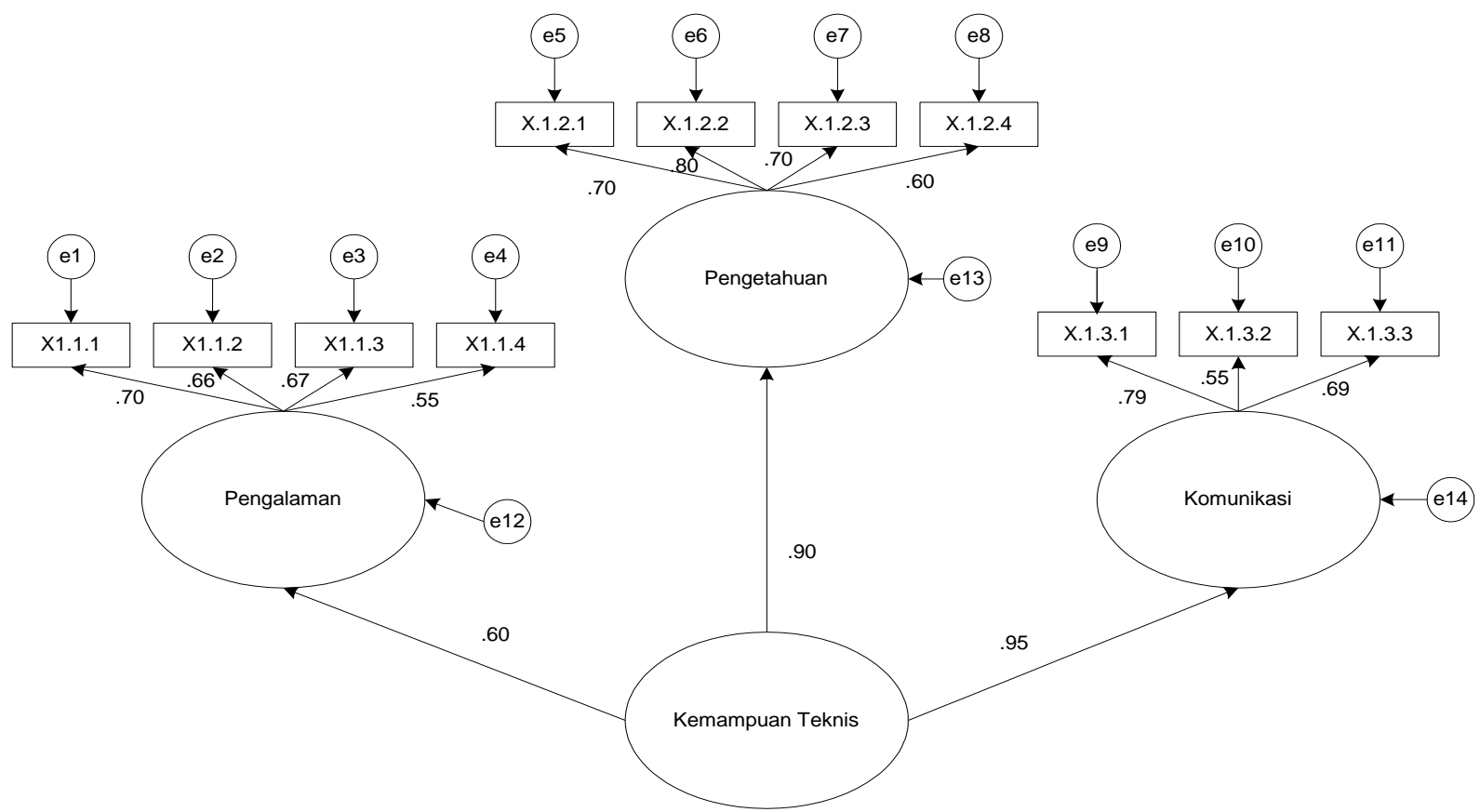

Gambar 1

CPA Second Order Kemampuan Teknis

Tabel 2

CFA Kualitas Informasi Laporan Keuangan

\begin{tabular}{rrrrr}
\hline \hline & Model Pengukuran & Std Loading & Std Loading & Error Variance \\
\hline $\mathrm{Y}_{1.1 .1}$ & $\leftarrow$ Standar Pekerjaan Umum & 0.601 & 0.361201 & 0.684 \\
$\mathrm{Y}_{1.1 .2}$ & $\leftarrow$ Standar Pekerjaan Umum & 0.85 & 0.7225 & 0.321 \\
$\mathrm{X}_{1.1 .3}$ & $\leftarrow$ Standar Pekerjaan Umum & 0.803 & 0.644809 & 0.395 \\
$\mathrm{Y}_{1.2 .1}$ & $\leftarrow$ Srandar Pelaporan & 0.705 & 0.497025 & 0.634 \\
$\mathrm{Y}_{1.2 .2}$ & $\leftarrow$ Keuangan & & Srandar Pelaporan \\
Keuangan & 0.554 & 0.306916 & 0.72 \\
$\mathrm{Y}_{1.2 .3}$ & $\leftarrow \begin{array}{l}\text { Srandar Pelaporan } \\
\text { Keuangan }\end{array}$ & 0.55 & 0.3025 & 0.709 \\
$\mathrm{Y}_{1.2 .4}$ & $\leftarrow \begin{array}{l}\text { Srandar Pelaporan } \\
\text { Keuangan }\end{array}$ & 0.649 & 0.421201 & 0.599 \\
$\mathrm{Y}_{1.2 .5}$ & $\leftarrow \begin{array}{l}\text { Srandar Pelaporan } \\
\text { Keuangan }\end{array}$ & 0.699 & 0.488601 & 0.47 \\
$\mathrm{Y}_{1.2 .6}$ & $\leftarrow \begin{array}{l}\text { Srandar Pelaporan } \\
\text { Keuangan }\end{array}$ & 0.603 & 0.363609 & 0.43 \\
$\mathrm{Y}_{1.2 .7}$ & $\leftarrow \begin{array}{l}\text { Srandar Pelaporan } \\
\text { Keuangan }\end{array}$ & 0.749 & 0.561001 & 0.641 \\
$\mathrm{Y}_{1.2 .8}$ & $\leftarrow \begin{array}{l}\text { Srandar Pelaporan } \\
\text { Keuangan }\end{array}$ & 0.699 & 0.488601 & 0.52
\end{tabular}




\begin{tabular}{rrrrr}
$\mathrm{Y}_{1.3 .1}$ & $\leftarrow \begin{array}{l}\text { Standar Pekerjaan } \\
\text { Lapangan }\end{array}$ & 0.65 & 0.4225 & 0.671 \\
$\mathrm{Y}_{1.3 .2}$ & $\leftarrow \begin{array}{l}\text { Standar Pekerjaan } \\
\text { Lapangan }\end{array}$ & 0.751 & 0.564001 & 0.507 \\
$\mathrm{Y}_{1.3 .3}$ & $\leftarrow \begin{array}{l}\text { Standar Pekerjaan } \\
\text { Lapangan }\end{array}$ & 0.802 & 0.643204 & 0.56 \\
\hline & $\quad$ Total & 9.665 & 6.787669 & 7.861 \\
\hline
\end{tabular}

Sumber : data penelitian (2019)

Berdasarkan tabel analisis CFA pada variabel kualitas audit yang dipaparkan pada Tabel 2, diketahui bahwa semua indikator yang membentuk tiap dimensi pada variabel kualitas informasi laporan keuangan bernilai melebihi 0,5. Dengan dapat disimpulkan bahwa indikator yang membentuk variabel kualitas informasi laporan keuangan sudah memenuhi validitas konvergen. Untuk mengetahui reliabilitas konstrak variabel kualitas audit, akan dihitung nilai construct reliability dengan rumus sebagai berikut:

Construct reliability $=\frac{\left(\sum \text { stdloading }\right)^{2}}{\left(\sum \text { stdloading }\right)^{2}+\sum e_{i}}$
$=(9,665)^{2} /\left(9,665^{2}+7,861\right)=0,922$

Dengan merujuk pada rumus di atas didapatkan nilai reliabilitas konstruk senilai 0,922 , dimana nilai tersebut telah melebihi 0,6 sehingga dapat dinyatakan bahwa variabel kualitas informasi laporan keuangan juga telah memenuhi construct reliability. Langkah selanjutnya dalam analisa model struktural adalah melakukan perkiraan parameter pengaruh antar variabel, yang pada akhirnya juga membuktikan hipotesa penelitian. Dibawah ini merupakan ikhtisar hasil estimasi parameter dari analisis SEM yang telah dilakukan:

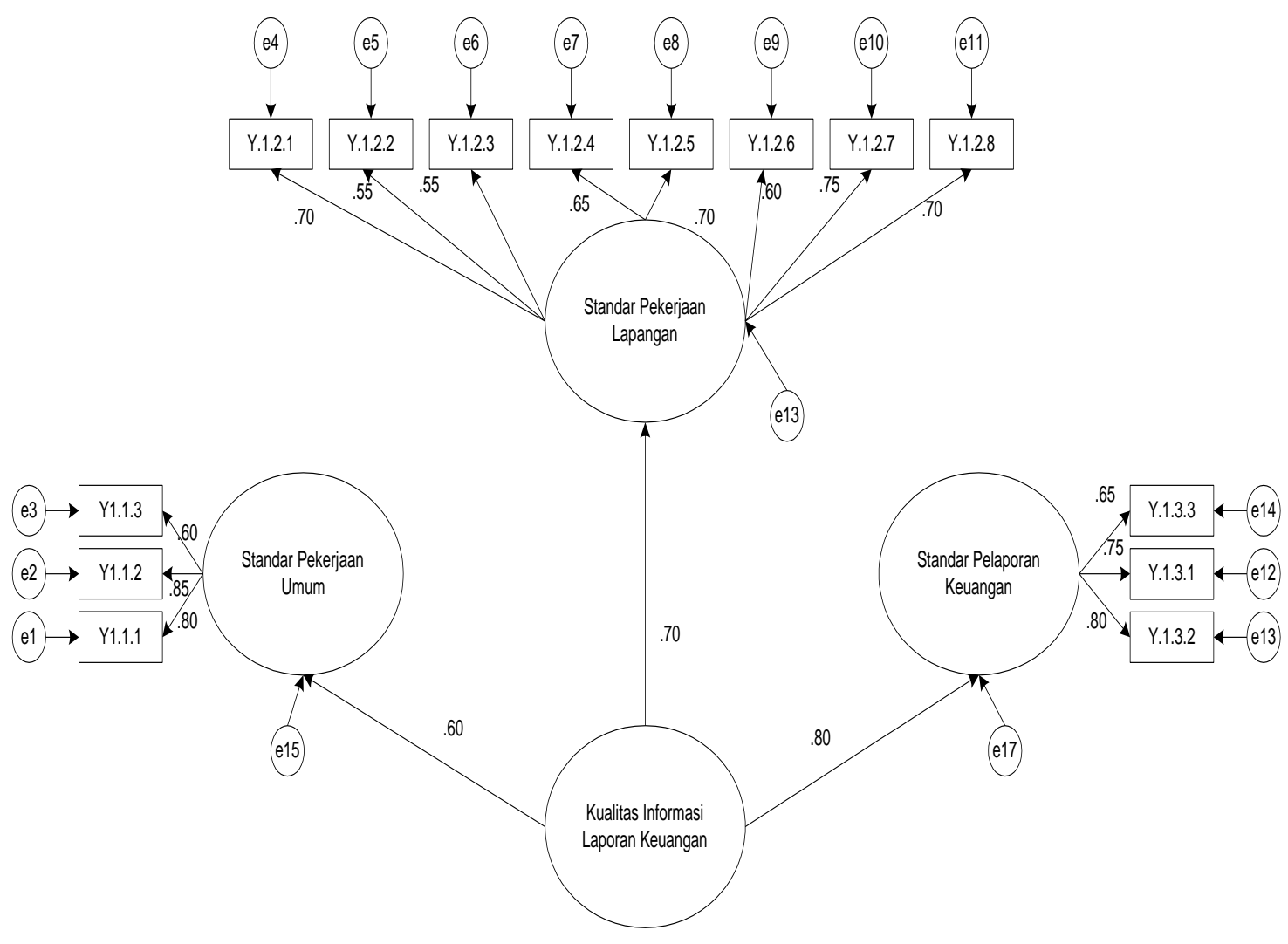

Gambar 2

CFA Second Order Kualitas Informasi Laporan Keuangan 
Tabel 3

Estimasi Parameter

\begin{tabular}{lcccc}
\hline \multicolumn{1}{c}{ Hubungan } & $\begin{array}{c}\text { Standar } \\
\text { Koefisien }\end{array}$ & C.R. & P value & Keterangan \\
\hline $\begin{array}{l}\text { Kemampuan } \\
\text { Teknis Auditor } \rightarrow\end{array}$ & 0.801 & 3.138 & 0.002 & Signifikan \\
$\begin{array}{l}\text { Kualitas Informasi } \\
\text { Laporan Keuangan }\end{array}$ & & & & \\
\hline
\end{tabular}

Berdasarkan hasil perkiraan parameter pengaruh antar variabel tersebut, maka bisa dilaksanakan pembuktian hipotesis penelitian mengenai pengaruh kemampuan teknis auditor terhadap kualitas informasi laporan keuangan adalah positif dengan besar pengaruh sebesar 0,801. Pengaruh yang dihasilkan kompetensi terhadap kualitas audit bersifat signifikan karena nilai $P$ value senilai 0,002 , dibawah 0,05 yang berarti hipotesis $H_{1}$ di terima dan Ho nya ditolak. Oleh karenanya hipotesa yang memaparkan bahwasanya kemampuan teknis auditor berpengaruh positif signifikan terhadap kualitas informasi laporan keuangan terbukti kebenarannya.

\section{Pembahasan}

Maksud dari pengaruh positif kemampuan teknis auditor pada kualitas informasi laporan keuangan adalah pada saat kemampuan teknis auditor meningkat maka kualitas informasi laporan keuangannya akan meningkat pula. Pemaparan ini sesuai dengan apa yang diungkapkan oleh SPAP bahwa persyaratan agar dapat dianggap mampu untuk melaksanakan tugas dibidang audit, maka auditor harus memenuhi dua hal, yakni, pertama, memiliki kemampuan teknis dan memiliki penataran teknis yang mencukupi sebagai auditor dan yang kedua, auditor wajib memiliki kecakapan profesionalitas dan keahlian dalam pelaksanaan tugasnya sebagai auditor. Hasil pengujian statistik yang menunjukkan adanya hubungan positif antara kemampuan teknis dan kualitas informasi laporan keuangan, menunjukkan bahwa untuk mencapai kualitas informasi laporan keua- ngan yang baik, maka auditor yang bersangkutan harus memiliki pengetahuan, pengalaman dan kemampuan komunikasi yang memadai. Karena dengan pengetahuan dan pengalaman yang baik maka auditor yang bersangkutan memiliki kemampuan untuk memilih prosedur audit yang sesuai dan efektif untuk digunakan dalam pelaksanaan rangkaian audit yang akan dilakukan. Selain itu, dengan komunikasi yang baik maka auditor yang bersangkutan akan sangat terbantu dalam proses pengumpulan bukti yang sesuai, yang akan digunakan sebagai dasar dalam penerbitan opini audit yang sesuai.

Hubungan positif antara kemampuan teknis dan kualitas informasi keuangan, sebagaimana dipaparkan dalam hasil penelitian ini mendukung empat teori dasar audit yang telah di jelaskan pada bagian sebelumnya. Dimana ketika kemampuan teknis auditor yang bersangkutan meningkat maka kualitas informasi dalam laporan keuangan juga akan meningkat. Hal ini sesuai dengan definisi dasar dari kualitas informasi laporan keuangan itu sendiri bahwa informasi dalam laporan keuangan dikatakan berkualitas apabila informasi tersebut dapat memberikan pemaparan yang utuh dan dapat menjadi tumpuan bagi para penggunanya dalam mengambil keputusan ekonomi. Informasi dalam laporan keuangan dapat dikatakan memiliki kualitas yang baik apabila informasi tersebut dapat menggambarkan kondisi entitas perusahaan yang menerbitkan laporan keuangan yang bersangkutan. Definisi tersebut sesuai dengan teori dasar audit yaitu teori Policeman Theory, dimana auditor dipersepsikan 
berposisi serupa dengan seorang polisi yaitu sebagai orang yang mampu untuk menemukan kesalahan pihak lain (dalam hal ini klien) dan memaparkan kesalahan tersebut dalam audit report. Selain itu dengan kualitas informasi yang baik maka auditor dapat menambahkan kredibilitas yang memadai terhadap informasi yang terpampang dalam laporan keuangan. Dimana hal ini sesuai dengan teori audit Credibility Theory, yang memaparkan bahwa fungsi utama dari audit adalah untuk menambahkan kredibilitas terhadap laporan keuangan. Dimana laporan keuangan yang teraudit semestinya dapat meningkatkan kepercayaan pengguna laporan keuangan terhadap segala informasi keuangan yang terpampang dalam laporan keuangan serta meningkatkan kepercayaan terhadap layanan yang diberikan oleh manajemen perusahaan. Credibility Theory ini menekankan pada kemampuan eksplanatori informasi dalam laporan keuangan untuk memberikan penjelasan yang dapat dipahami oleh pengguna informasi keuangan dalam rangka untuk mengambil keputusan ekonomi.

Hubungan positif antara kemampuan teknis auditor dan kualitas informasi yang terpampang dalam laporan keuangan juga sesuai dengan penjelasan Information theory dimana dalam teori ini dijelaskan bahwa pengambilan keputusan merupakan bagian intrinsic dari praktek masa kini dalam ranah akuntansi. Pengambilan keputusan merupakan dasar dari timbulnya permintaan atas layanan yang disuguhkan oleh para akuntan dan hal tersebut melibatkan tugas yang tidak mudah. Pertama, pernintaan atas layanan para akuntan, yaitu informasi, adalah sesuatu yang disebabkan oleh mereka yang meyakini bahwa informasi akuntansi akan membantu mereka dalam pembuatan keputusan. Investor, para pemberi pinjaman, pegawai, pemerintah dan manajemen perusahaan merupakan para pihak yang terpengaruh oleh informasi yang disajikan oleh para akuntan. Kedua, akuntan sendiri diperlukan karena adanya keperluan untuk mengambil sejumlah keputusan kompleks.
Dengan adanya hubungan positif antara kemampuan teknis dan kualitas informasi yang bersangkutan maka dapat dikatakan bahwa ketika kemampuan teknis dari auditor yang bersangkutan meningkat maka, auditor tersebut dapat menghasilkan informasi keuangan yang diyakini dapat membantu dalam mengambil keputusan investasi dan keputusan kompleks lain yang berkaitan dengan keberlangsungan entitas perusahaan yang bersangkutan.

\section{SIMPULAN DAN SARAN \\ Simpulan}

Dengan merujuk pada hasil pengujian yang telah dipaparkan sebelumnya maka dapat dinyatakan bahwa kemampuan teknis auditor berpengaruh positif signifikan terhadap kualitas informasi laporan keuangan. Hasil ini seiring dengan hasil penelitian terdahulu yang telah dilaksanakan oleh Agusti dan Pertiwi (2013), Ilmiyanti dan Suhardjo (2012), dan Tjun et al., (2013) mengenai pengaruh keahlian teknis terhadap kualitas informasi laporan keuangan.

Dimana penelitian terdahulu menjelaskan bahwa kecakapan teknis berpengaruh secara positif signifikan terhadap kualitas informasi laporan keuangan. Hasil pengolahan statistik sesuai dengan pemaparan empat teori audit yang telah di paparkan pada bagian tinjauan teoritis, bahwa pelaksanaan audit didasarkan pada empat teori utama yaitu Policeman Theory, Credibility Theory, Information Theory dan Assurance Theory.

Keempat teori tersebut menjelaskan secara runtut bahwa audit merupakan satu paket lengkap yang dilaksanakan mulai dari prinsip dasar bahwa tugas utama auditor adalah menemukan adanya kejanggalan dan kecurangan selama proses audit berlangsung, menambahkan kredibilitas infomasi keuangan pada laporan keuangan yang diterbitkan, memaparkan informasi tersebut secara informative tanpa ada bagian-bagian yang ditutupi serta memberikan jaminan bahwa informasi yang disajikan telah bebas dari salah saji yang material dalam segala 
hal. Pada akhirnya, hubungan positif antara kemampuan teknis auditor dan kualitas informasi dalam laporan keuangan mencerminkan fungsi assurance, sebagaimana dijelaskan dalam Policeman Theory, Credibility Theori, Information Theory, dan Assurance theory. Bahwa fungsi utama dari audit adalah memberikan assurance (jaminan) kepada para pengguna informasi keuangan. Assurance tersebut akan dapat diberikan pada pengguna laporan keuangan jika auditor yang bersangkutan memiliki kemampuan teknis yang memadai untuk dapat menghasilkan informasi yang terjamin kewajarannya dalam rangka pengambilan keputusan ekonomi.

Dimana kemampuan teknis tersebut terdiri dari pengetahuan, pengalaman dan komunikasi. Pengetahuan dapat membawa auditor yang bersangkutan pada kemampuan untuk memilih prosedur audit yang sesuai dalam rangka pengumpulan bukti, pengalaman atau jam terbang yang cukup dalam pelaksanaan audit dapat membawa pada insting yang lebih peka sebagai seorang auditor dalam mendeteksi terjadinya kecurangan dan salah saji yang material, sedangkan kemampuan komunikasi yang baik akan membawa auditor yang bersangkutan untuk dapat berkomunikasi dengan baik terhadap kliennya sehingga kebutuhan informasi yang dibutuhkan dapat terpenuhi.

Mengingat audit bukan hanya sekedar proses untuk memenuhi daftar prosedur dan memahami pos-pos penyesuaian akuntansi saja. Tetapi audit merupakan suatu proses yang menyeluruh dimana auditor sebagai pelaksana audit, tidak hanya dituntut menjadi seseorang yang memiliki pemaha man teknis tetapi juga mampu berkomunikasi secara efektif dan mau berkomunikasi secara langsung dengan klien guna mengarahkan klien agar dapat secara sukarela memaparkan gambaran kondisi keuangan yang terjadi pada perusahaan, dalam rangka pengumpulan bukti audit yang memadai sebagai dasar dalam penyusunan opini audit.

\section{Saran}

Penelitian ini memiliki beberapa keterbatasan. Pertama, penelitian ini dilakukan dengan menggunakan metode angket, dimana angket kuesioner diserahkan kepada responden untuk selanjutnya diisi dan dikembalikan oleh responden beberapa hari setelah angket kuesioner tersebut selesai diisi. Dimana angket kuesioner tersebut tidak dapat secara langsung diisi dan dikembalikan. Kedua, penelitian ini hanya menggunakan variabel kemampuan teknis auditor sebagai variabel independen yang mempengaruhi kualitas informasi laporan keuangan. Berdasarkan penjelasan mengenai keterbatasan dalam penelitian ini, maka penelitian yang akan datang dapat menyempurnakan kekurangan penelitian ini dengan beberapa cara, diantaranya, pertama, melakukan pengambilan data dengan cara focus group discussion sehingga bisa mendapatkan data secara langsung dan dapat melakukan pengawasan secara langsung pada saat pengumpulan data, sehingga dapat dilakukan tanya jawab pada saat pengisian angket kuesioner berlangsung, agar peneliti juga dapat memahami bilamana terdapat butir-butir pernyataan yang kurang jelas, sehingga data yang diperlukan menjadi lebih valid. Selain itu, dengan dilakukannya focus group discussion, maka peneliti dapat melakukan pengawasan langsung untuk dapat mengetahui apakah angket kuesioner tersebut telah diisi oleh orang yang bersangkutan atau bukan. Kedua, penelitian selanjutnya dapat menggunakan variabel lain yang dinilai dapat mempengaruhi kualitas informasi laporan keuangan, diantaranya seperti karakter yang dimiliki oleh auditor. Ketiga, penelitian selanjutnya dapat mempertimbangkan untuk melakukan mix method sehingga selain dengan menggunakan butir pernyataan kuesioner, peneliti selanjutnya bisa mendapatkan jawaban lebih mendalam melalui wawancara dengan subyek penelitian mengenai faktor-faktor lain yang dianggap berpengaruh terhadap kualitas informasi yang tertera dalam laporan keuangan. 


\section{DAFTAR PUSTAKA}

Achim, A. M. dan A. O. Chiş. 2014. Financial Accounting Quality And Its Defining Characteristics. SEA: Practical Application of Science 2(3).

Agusti, R. dan N. P. Pertiwi. 2013. Pengaruh Kompetensi, Independensi dan Profesionalisme Terhadap Kualitas Audit (Studi Empiris Pada Kantor Akuntan Publik Se Sumatera). Jurnal Ekonomi 21(03): 1-13.

Ajao, O. S., J. O. Olamide, dan A. A. Temitope. 2016. Evolution and Development of Auditing. Unique Journal of Business Management Research 3(1): 032-040.

Akther, T. dan F. Xu. 2020. Existence of the Audit Expectation Gap and Its Impact on Stakeholders' Confidence: The Moderating Role of the Financial Reporting Council. International Journal of Financial Studies 8(4): 1-25.

Ali, N. A. M., S. Shahimi, dan Z. Shafii. 2018. Knowledge, Skills and Characteristics Requirements for Shari'ah Auditors. Asian Journal of Accounting and Governance 9: 171-185.

Amrin, A. 2016. Data Mining Dengan Regresi Linier Berganda Untuk Peramalan Tingkat Inflasi. Jurnal Techno Nusa Mandiri 13(1): 74-79.

Arel, B. 2010. The influence of litigation risk and internal audit source on reliance decisions. Advances in Accounting 26(2): 170-176.

Boiral, O., L. Heras-Saizarbitoria, dan M.-C. Brotherton. 2019. Professionalizing the Assurance of Sustainability Reports: the Auditors' Perspective. Accounting, Auditing $\mathcal{E}$ Accountability Journal 33(2): 309334.

Brown, V. L., J. L. Gissel, dan D. G. Neely. 2016. Audit Quality Indicators: Perceptions of Junior-Level Auditors. Managerial Auditing Journal 31(8/9): 949-980.

Brunelli, S. 2018. Audit Reporting for Going Concern Uncertainty: Global Trends and the Case Study of Italy: Springer. Switzerland.
Butar-Butar, S. dan S. L. I. L. Indarto. 2018. Does Auditor Industry Expertise Improve Audit Quality In Complex Business Environments? Jurnal Akuntansi dan Keuangan 20(1): 1-12.

Butcher, K., G. Harrison, dan P. Ross. 2013. Perceptions of Audit Service Quality and Auditor Retention. International Journal of Auditing 17(1): 54-74.

Chadegani, A. A. 2011. Review of Studies on Audit Quality. International Conference on Humanities, Society, and Culture IPEDR 20(2011): 312-317.

Christensen, B. E., S. M. Glover, T. C. Omer, dan M. K. Shelley. 2016. Understanding Audit Quality: Insights from Audit Professionals and Investors. Contemporary Accounting Research 33(4): 16481684.

Christensen, B. E., S. M. Glover, dan D. A. Wood. 2012. Extreme Estimation Uncertainty in Fair Value Estimates: Implications for Audit Assurance. Auditing: A Journal of Practice $\mathcal{E}$ Theory 31(1): 127-146.

Dauda, A., dan B. V. Olawale. 2019. The Place of Auditing in Organizational Performance of Public Sector: Evidence from some selected Local Government in Zamfara State, Nigeria. Journal of Accounting and Financial Management 5(2): 10-17.

DeFond, M., dan J. Zhang. 2014. A Review of Archival Auditing Research. Journal of Accounting and Economics 58(2-3): 275326.

Eid, A., dan E. Mahmoud. 2014. The Impact of Accounting Information Systems (AIS) on Performance Measures With Value Relevance of Auditors' communications. Internal Auditing \& Risk Management IX(2): 13.

Elbannan, M. A. 2011. Accounting and Stock Market Effects of International Accounting Standards Adoption in an Emerging Economy. Review of Quantitative Finance and Accounting 36(2): 207-245.

Ernstberger, J., C. Koch, dan H.-T. Tan. 2015. What Dimensions of Lead Auditor 
Expertise Matter for Audit Quality and Audit Fees? Behavioral \& Experimental Accounting eJournal (2015).

Francis, J. R. 2011. A Framework for Understanding and Researching Audit Quality. AUDITING: A Journal of Practice $\mathcal{E}$ Theory 30(2): 125-152.

Francis, J. R. dan M. D. Yu. 2009. Big 4 Office Size and Audit Quality. The Accounting Review 84(5): 1521-1552.

Herath, S. K. dan N. Albarqi. 2017. Financial Reporting Quality: a Literature Review. International Journal of Business Management and Commerce 2(2): 1-14.

Hope, O.-K., W. Thomas, dan D. Vyas. 2011. Financial Credibility, Ownership, and Financing Constraints in Private Firms. Journal of International Business Studies 42(7): 935-957.

Hussein, F. E. dan M. MohdHanefah. 2013. Overview of Surrogates to Measure Audit Quality. International Journal of Business and Management 8(17): 84-91.

Ilmiyati, F. dan Y. Suhardjo. 2012. Pengaruh Akuntabilitas dan Kompetensi Auditor terhadap Kualitas Audit. JURAKSI: Jurnal Akuntansi 1(1): 43-56.

Jönsson, F. dan J. Ottosson. 2015. Mandatory Rotation of Audit Firms: A study on the investors' viewpoints in the EU and the US. Thesis. Jönköping International Business School. Jönköping, Swedia.

Libby, R. 2017. Accounting and Human Information Processing. The Routledge Companion to Behavioural Accounting Research: 42-54.

Lim, Y.-M., T. H. Lee, C. S. Yap, dan C. C. Ling. 2016. Employability Skills, Personal Qualities, and Early Employment Problems of Entry-level Auditors: Perspectives from Employers, Lecturers, Auditors, and Students. Journal of Education for Business 91(4): 185-192.

McNamara, J. 2013. The Challenge of Assessing Professional Competence in Work Integrated Learning. Assessment $\mathcal{E}$ Evaluation in Higher Education 38(2): 183197.
Mkoba, E. dan C. Marnewick. 2016. IT Project Success: a Conceptual Framework for IT Project Auditing Assurance. Proceedings of the Annual Conference of the South African Institute of Computer Scientists and Information Technologists: 1-8.

Nwanyanwu, L. A. 2017. Audit Quality Practices and Financial Reporting in Nigeria. International Journal of Academic Research in Accounting, Finance and Management Sciences 7(2): 145-155.

Oliván, J. B. 2017. Communication as an Element of Knowledge for the Company's Human Resources. Procedia-Social and Behavioral Sciences 237: 1533-1536.

Publik, I. A. I. K. A. 2011. Standar Profesional Akuntan Publik. Salemba Empat. Jakarta.

Rezaee, Z., J. Abernathy, M. Causholli, P. N. Michas, P. B. Roush, S. Rowe, dan U. K. Velury. 2016. Comments of the Auditing Standards Committee of the Auditing Section of the American Accounting Association on PCAOB Concept Release on Audit Quality Indicators, No. 2015005, July 1, 2015: Participating Committee Members. Current Issues in Auditing 10(1): C11-C27.

Robertson, J. C. 2010. The Effects of Ingratiation and Client Incentive on Auditor Judgment. Behavioral Research in Accounting 22(2): 69-86.

Salehi, M. 2010. Evaluating Effectiveness of External Auditors' Report: Empirical Evidence from Iran. Pakistan Journal of Commerce and Social Sciences (PJCSS) 4(1): 69-83.

Salifu, I. dan M. Mahama. 2015. The Evaluation of Evidence of the Audit Expectation Gap in Ghana. Research Journal of Finance and Accounting 6(24): 20-30.

Sarstedt, M., C. M. Ringle, D. Smith, R. Reams, dan J. F. Hair Jr. 2014. Partial Least Squares Structural Equation Modeling (PLS-SEM): a Useful Tool for Family Business Researchers. Journal of Family Business Strategy 5(1): 105-115.

Sawani, Y., M. Mohamed Zain, dan F. Darus. 
2010. Preliminary Insights on Sustainability Reporting and Assurance Practices in Malaysia. Social Responsibility Journal 6(4): 627-645.

Smith, J., R. Haniffa, dan J. Fairbrass. 2011. A Conceptual Framework for Investigating 'capture' in Corporate Sustainability Reporting Assurance. Journal of Business Ethics 99(3): 425-439.

Steinbart, P. J., R. L. Raschke, G. Gal, dan W. N. Dilla. 2012. The Relationship between Internal Audit and Information Security: an Exploratory Investigation. International Journal of Accounting Information Systems 13(3): 228-243.

Suyono, E. 2012. Determinant Factors Affecting the Audit Quality: an Indo- nesian Perspective. Global Review of Accounting and Finance 3(2): 42-57.

Tjun, L. T., E. I. Marpaung, dan S. Setiawan. 2013. Pengaruh Kompetensi dan Independensi Auditor terhadap Kualitas Audit. Jurnal Akuntansi Maranatha 4(1): 33-56.

Wong, R. dan A. Millington. 2014. Corporate Social Disclosures: a User Perspective on Assurance. Accounting, Auditing $\mathcal{E}$ Accountability Journal 27(5): 863-887.

Ziefle, M. dan A. K. Schaar. 2010. Technical Expertise and Its Influence on the Acceptance of Future Medical Technologies: What is Influencing What to Which Extent? Symposium of the Austrian HCI and Usability Engineering Group: 513529. 